\title{
Opportunities and challenges for research in systematic and evolutionary botany in Latin America
}

\section{Oportunidades y desafíos para investigaciones en la sistemática vegetal y evolución en America Latina}

\section{Tod F. Stuessy ${ }^{1,2}$}

${ }^{1}$ Herbarium and Department of Evolution, Ecology, and Organismal Biology, The Ohio State University, 1315 Kinnear Road, Columbus, Ohio 43212, USA.

${ }^{2}$ Department of Botany and Biodiversity Research, University of Vienna, Rennweg 14, A-1030 Vienna, Austria.

*E-mail: stuessy.1@osu.edu

\section{ABSTRACT}

The floras of countries of Latin America offer research opportunities on numerous significant themes, such as: adaptation in diverse habitats, island biogeography, speciation in high mountain ecosystems, evolution in lowland tropical zones, and impact from Pleistocene glaciation. Because these biological perspectives transgress country borders, collaboration among investigators is essential. Latin America contains approximately 110,000 native vascular plant species, or $29 \%$ of the world's flora. A more precise inventory is needed for construction of more predictive classifications and interpretation of macro- and microevolutionary processes. One solution for providing deeper inventorying would be employment of young and low-income parataxonomists on a massive scale, organized in a Cuerpo de Patrimonio Nacional within each country. Another priority is botanical monography, especially with a broad evolutionary focus. Literature accessibility and digital images of herbarium material from the Internet support monographic work more than ever before. Travel for monographic field work across borders is also most important so that relationships within entire natural plant groups can be revealed. The Internet offers opportunities for online publishing of monographs with deeper visual content and hence greater outreach for other sectors of society. Impact factors have become accepted world-wide for administrative evaluation of professional achievement, and it is recommended that strategies be adopted for maximizing their usefulness for career development. To stimulate cooperative work with scientists outside of Latin America, those within the region must become more proficient in English, including giving talks in this language at international meetings. English proficiency allows digestion of the international literature and opens doors to asking fundamental biological, rather than just regional, questions.

Keywords: English proficiency, floristics, impact factors, monography, parataxonomists.

\section{RESUMEN}

Las floras de los países de América Latina ofrecen oportunidades para investigar temas numerosos y significativos, como son la adaptación en ambientes diversos, la biogeografía de islas, la especiación en ecosistemas de la alta montaña, la evolución en zonas tropicales, y los impactos de la glaciación durante el Pleistoceno. Estas perspectivas amplias traspasan las fronteras de los países, lo cual sugiere el desarrollo de colaboraciones internacionales. Latinoamérica contiene ca. 110,000 especies vasculares y nativas, lo que representa aproximadamente un $29 \%$ de la flora mundial. Falta todavía un inventario más preciso para la construcción de clasificaciones más predictivas y la interpretación de procesos de macro- y microevolución. Una solución para llegar a un inventario más completo puede ser la contratación de un nivel numeroso de jóvenes en necesidad de ayuda económica 
como parataxónomos, todos ellos organizados en un Cuerpo de Patrimonio Nacional dentro de cada país. Otra prioridad es la monografía botánica, especialmente con enfoques evolutivos amplios. El acceso a la literatura y fotos digitales de muestras del herbario apoyan el trabajo monográfico como nunca antes. Los viajes al campo que cruzan fronteras internacionales son indispensables para investigar las relacciones evolutivas dentro de grupos naturales. El Internet ofrece oportunidades para publicar monografías con más contenido visual, lo cual puede servir mejor a otros sectores de la sociedad. Los factores de impacto se han aceptado mundialmente para la evaluación administrativa del éxito profesional, y se recomienda que se adopten estrategias para maximizar su utilidad en el desarrollo de una carrera profesional. Para estimular las investigaciones colaborativas entre científicos de países fuera de América Latina, se sugiere aumentar la competencia del inglés, incluyendo el uso de este idioma durante las presentaciones que se efectúan en conferencias internacionales. Además, un dominio del inglés abre las puertas a la literatura mundial y apoya las investigaciones sobre temas biológicos internacionales en vez de sólo regionales.

Palabras clave: competencia en inglés, factores de impacto, florística, monografía taxonómica, parataxónomos.

\section{INTRODUCTION}

Latin America covers approximately $13 \%$ of the terrestrial surface of our planet, ranging from Mexico in the Northern Hemisphere to Chile and Argentina in the Southern Hemisphere. In between are a bewildering series of bold, diverse landscapes that contain a high diversity of plant species. Within this panorama must reside opportunities for significant research in systematic and evolutionary botany, such as investigations on: plant adaptations in diverse habitats, evolution in tropical climates, island biogeography and evolution, speciation and radiation in the Andean zone, and biogeographic effects of Pleistocene glaciation. In other words, there is no lack of opportunity for international-level research in systematic and evolutionary botany in Latin America.

To address research questions regarding relationships among species and their evolution in the flora of Latin America requires having a good inventory of the flora. Although the recent assessment by Ulloa et al. (2017) is a major step toward having that inventory, it is only a beginning due to the large number of unknown species that reside within the region, estimated between 10-20\% more still undiscovered (Pimm \& Joppa 2015). With such missing information, it is difficult to assess evolutionary relationships among species of a natural group, because taxonomic gaps distort understanding of relationships among the already known species. Likewise, to examine processes of evolution requires investigating close relatives, and if species are absent, it makes these studies less than conclusive. This suggests looking hard for new solutions to having a more complete inventory of the vascular flora of Latin America.
With a better understanding of the flora of the region, it becomes possible to complete monographic taxonomic investigations that can be stimulating for asking evolutionary and biogeographic questions. A botanical monograph is the basic statement of plant relationships, in which are sketched the nature of species, their characteristics, distributions, and relationships to each other (Stuessy \& Lack 2011). With these facts, it is possible to offer hypotheses regarding the origin of the diversity and its spatial and ecological contexts. Monographic investigation is the basis for all other research in systematic and evolutionary botany and must be encouraged.

There has been much discussion of the problems associated with impact factors for evaluation of research performance within Latin America, and another look at the problem is warranted. With financial resources limited within Latin American countries, it may seem unfair to use the same yardstick for measuring research quality and productivity as in developed countries with larger research budgets (Rochmyaningsih 2017). On the other hand, using a transparent metric may be more desirable than suffering intuitive decisions made by administrators unfamiliar with specific areas of research. The best strategy may be to simply adjust to use of these metrics of performance rather than attempting to resist their use.

Latin America has long been language-restricted, which has limited to some extent progress in international contributions to basic science. Because English is the modern medium for scientific communication, more emphasis should be placed on this within Latin America, including during the Latin American Botanical Congress. If English preparation begins in earnest in primary schools and continues through university, a good start toward reading the world's literature 
and attending international conferences will have been made.

The purposes of this paper are to discuss these issues in more detail, and specifically to: (1) advocate a deeper understanding of phytodiversity in Latin America by use of parataxonomists on a massive scale; (2) encourage more taxonomic and evolutionary monography for understanding species and their relationships, and to use these to stimulate further investigations on biogeography and evolutionary processes; (3) recommend accepting impact factors as a fixture of modern administrative evaluation and using them to develop successful career strategies; and (4) suggest increased use of English throughout Latin America and especially in international conferences.

\section{PHYTODIVERSITY}

There is a very large number of vascular plant species in Latin America, approximately 110,000, which represents about $29 \%$ of the world's flora (Ulloa et al. 2017). With such a large number of species, and considering that each country wishes to inventory carefully its natural resources, it would seem logical that there would be a very high priority placed on floristic research throughout the region. Progress has been made with inventorying different regions, with publications on the local, state, national, and regional levels. Recent important contributions have been the catalogue of the vascular plants of the Southern Cone (Zuloaga et al. 2008) and a checklist of the native vascular plants of Mexico (Villaseñor 2016), among many others, including digital versions (e.g., of the flora of the Juan Fernández Archipelago, Chile; Penneckamp 2018).

Nevertheless, we are still a very long way from having a solid inventory of the vascular plants of Latin America. In general, there exists an understanding of which areas of the world need more collecting activity (Kier et al. 2005), and Latin America is one of these significant regions (especially the Andean countries; Joppa et al. 2011). At the same time, the human population continues to grow with activities that pressure the native plant world. It gives the unmistakable impression that much phytodiversity will be lost before we will have the chance to inventory and understand it. There is a paradox: many funding agencies place emphasis on research involving hypothesis-testing, which means resources are directed to laboratory rather than field work. A more dramatic approach for floristic inventorying may be needed.

A plan should be developed within each country to be called the Cuerpo de Patrimonio Nacional. The idea is to contract young persons in need of employment for a period of at least five years, under supervision of botanists, to collect in regions of each country under threat of destruction, or regions simply poorly known, and following existing priorities established by conservation organizations. The emphasis is on providing work for people, especially younger unemployed persons. The key here is to think in terms of thousands of persons, those who need jobs and are willing to learn and work for the good of the country (and for science in general). These workers, parataxonomists (Janzen 1991), will gain skills that should allow them to find jobs after the contracts are finished, attributes such as development of discipline, experience of working within teams, and learning how to deal with logistics and planning. Potential future employment might be as teachers, guides for ecotourism, assistants in biodiversity and forestry industries, or field workers for environmental consultants. Politicians may have little or no interest in phytodiversity, but they understand the importance of jobs for workers in their countries. This initiative combines the political strength of helping lower income persons and the search for potentials of natural resources within each country.

Employment of parataxonomists in pilot programs has shown to be successful (Basset et al. 2000, 2004), if managed properly, and much of the experience has come from entomological efforts in Costa Rica. Other projects also have been completed in South Africa, Kenya, Papua New Guinea, Gabon, Guyana, and the U.S.A. (Basset et al. 2004). From initiation of the idea in the early 1990 s, various training sessions in Costa Rica have been developed and more than 30 years of experience have been chronicled. The objectives of collection have to be outlined clearly, and the training programs must be administered according to these inventory goals. The experience in Costa Rica reveals training can take up to six months (or about 1000 hours; Reid et al. 1993), but these have involved insects with different life stages that necessitated rearing from larvae to adult. Plants do not have such dramatic metamorphoses. The size of the recommended programs would require considerable investment in proper training to be successful.

Another benefit accruing from the activities of parataxonomists is to serve as a better conduit of biodiversity information from scientists to the communities and companies, which are stewards of the natural resources within each country. These newly trained individuals will communicate the importance of biodiversity to friends and relatives within their sphere of social contacts, and this can have a positive impact on social development within the country (Schmiedel et al. 2016). It is realized that parataxonomists may not see "morphospecies" in nature at the same level of discrimination as professional taxonomists (Krell 2004), but the overall gain of new specimens will more than compensate for any overlooked taxa in the field. Costs for storage of the thousands of new specimens will also have 
to be calculated in the plan so that the collection resources will be a permanent addition to understanding the natural resources of each country. Co-operative programs with researchers in other institutions should also be developed to allow these specimens to be studied further, such as analysis of DNA variation (routine barcoding; Janzen \& Hallwachs 2011), but this would have to be handled carefully to avoid concerns regarding loss of biological heritage.

Funding for such programs would usually come from within each country, but additional stimulus might come from the Organization of American States (OEA), World Bank, AID, United Nations, or other higher-level agencies. Getting access to these funds would have to be done at the highest financial and political levels within each country. This is not an easy agenda, especially because most scientists are not attracted to the political world, which deals largely with influence and power (especially over financial resources). Nonetheless, for success in developing a massive inventorying program, political involvement by the botanical establishment must be accomplished, especially from persons in natural resources, conservation, and tourism.

\section{TAXONOMIC AND EVOLUTIONARY MONOGRAPHY}

In addition to knowing the existence of species in Latin America, we need to understand the taxonomic and evolutionary relationships among these taxa. This type of information is contained within the botanical monograph, which provides the basic statement of phytodiversity (Stuessy 1993; Stuessy \& Lack 2011). Here one finds data about taxa, their characteristics, distributions, botanical history, plus hypotheses of relatedness, which form the basis for construction of phylogenetic trees. From this come inferences on processes of evolution and biogeography. The monograph is also fundamental for categorizing scarcity of each taxon, which is necessary for developing conservation strategies. Without new monographs, it is impossible to make progress in systematic and evolutionary botany.

There are three basic types of monographic publications (Stuessy 1975): synopsis, revision, and monograph. All contain information about species, but the depth of information differs. The synopsis is a beginning toward understanding a group, and perhaps not all species have been included, not all nomenclature has been resolved, and only some relationships have been discussed. A revision is more comprehensive, providing complete coverage of the species within the group (often a genus or natural subdivision of one), which means descriptions, distribution maps, complete nomenclature, keys, and comments on relationships. A monograph contains the same fundamental and comprehensive data as in the revision, but more biological or historical information is included. This might include data from cytology, anatomy, or DNA sequences, plus also interpretations of biogeography, phylogeny, and even processes of speciation.

The minimal data that should be presented in a botanical monograph are morphology, distributions, ecology, and nomenclature. These data serve to delimit what the species are like, where they are located, and what their proper names should be. Other significant data might be chromosome numbers, which combined with distributions and understanding of relationships, can help infer modes of speciation (e.g., Sundberg \& Stuessy 1990). Also important is a quantitatively prepared phylogeny (based on morphological or preferably molecular data). These data allow a predictive classification to be constructed, which is the most important aspect of the monograph. It is essential that a monograph deal with a monophyletic group (s.l.). It makes no sense to construct a predictive classification and infer evolutionary processes if the species are not close relatives to each other.

A thoughtfully prepared monograph can be very stimulating for other workers interested in evolutionary processes. A useful example of how a monograph may stimulate research on modes of speciation is Pozoa (Umbelliferae). This is a small genus of only two closely related species confined to the southern Andes of Chile and adjacent Argentina. A revision of this group was produced by Mathias and Constance in 1962; especially compelling were the figures of the two species and the maps of their distributions, with $P$. coriacea being wide-ranging and $P$. volcanica very restricted. This suggested that the latter species might have evolved from the former. Chloroplast DNA comparisons among genera closely related to Pozoa and studies with AFLP data among populations of the two species confirmed that $P$. volcanica originated from $P$. coriacea via progenitor-derivative speciation (López et al. 2012).

Another productive approach that can derive from the monograph is to examine adaptive values of morphological characters. Once the taxonomy has been clarified, the idea is to construct hypotheses on how morphological features permit adaptation (survival and fitness) to the environment, and then to test these ideas. An advantage is that these studies do not require huge amounts of travel, often being done locally. An example in Espeletia (Asteraceae) comes from Monasterio and Sarmiento (1991), where they investigated leaves in context of water relations within the plant (i.e., how the leaves allow survival in a difficult environment). Another example is an investigation into the adaptive value of nodding heads in Culcitium canescens in the páramos of 
Ecuador (Sklenár 1999). Tests were done that revealed higher temperatures of the fruits in the nodding heads, which aided in fruit development.

Monographs can also stimulate hypotheses of biogeography. Once the taxonomy of a group has been clarified with relationships and distributions presented, it is possible to ask more sophisticated questions regarding biogeographic events. In addition to distributions, other data are important, depending upon the nature of the questions being asked: vegetation zones, soils, environmental parameters (especially temperature and rainfall), and paleoenvironmental data. Dating of events is also important, and this involves having fossil evidence and molecular dating methods. In Latin America there have been many earth events that have helped shape phytodiversity, such as the origin of the Andes, local volcanism, the origin (or changes) of rivers, lakes, or oceans, impacts from glaciation, fires, and the impact of humans during historical time. In addition, the correlations of climatic factors with present distributions, such as with WorldClim, has led to the ability to predict distributional changes based on hypotheses of environmental change, including from global warming.

Monographs should also attempt to reach a broader audience than just other systematic botanists (Marhold \& Stuessy 2013). The Internet offers many tools for better dissemination of taxonomic information contained within a monograph (Mayo et al. 2008; Wen et al. 2015). With a digital presentation, there is virtually no limit to the amount of photographs of characters and habitats that can be included, and this at reasonable expense. Another useful addition is an online illustrated polyclave, making keying an easier and more educational experience, especially for persons not very familiar with the group in question. These modifications can greatly increase the impact of monographs in society as a whole.

Latin America offers distinct advantages for being able to produce taxonomic monographs. If they are endemic to a country, species may grow conveniently close to the home institution to facilitate initiation of research. Costs for the production of a monograph are usually much less than with molecular laboratory research. These approaches are certainly not exclusive of each other, and in fact, they can be combined fruitfully, but monography has a bold role to play within Latin America because there are so many genera that are not very well understood. It is concerning that funding has been steered in recent decades into molecular phylogenetic work, and sometimes to the exclusion of monographic research. The good news is that with new Internet tools, working on a taxonomic monograph is easier than ever before. The needs for monography require access to an herbarium (for loans to be received), a dissecting scope, funds for field work, and access to the Internet. Previously, access to a major botanical library would have been requisite, but Internet resources now provide access to historical literature and digital images of type specimens. Travel is still needed for field work to understand patterns of morphological variation within and among populations, but there is now less need to travel to major botanical institutions in Europe or the U.S.A. to consult literature or type specimens.

Too many monographic studies in Latin America are done solely within the confines of one country. Research on taxonomic groups can be seriously limited by lack of access to populations in adjacent countries. Too much research focuses on "genus $X$ in country $Y$ " rather than on an entire natural group wherever it grows. Funds need to be generated to abrogate this problem. Floristic inventories naturally are confined within a political area, but this is not the case for monographic work. Travel to all geographic areas of interest needs to be completed, either by the single investigator or by collaboration with co-workers in adjacent countries. The ideal solution would be to have a very large permanent (endowment) fund at the level of the Organization of American States (OEA), something like U.S. $\$ 10,000,000$ that would generate c. $\$ 500,000$ per year, or providing 100 grants of $\$ 5,000$ each (perhaps evaluated by a committee of the Red Latinoamericana de Botánica). This could have a major impact on research in the region. The challenge again, however, is that acquiring large sums of money through personal and political contacts predicates considerable effort, time, and especially patience.

\section{IMPACT FACTORS}

A topic of significance for Latin American researchers is use of impact factors. These are numerical measurements of how often journal articles are cited in other journals, the idea being that a more frequently cited article is one that is having a greater scientific impact. Evaluating the quality of scientific publications is not an easy task, accomplished most effectively by experts in the very same field. As is well known, the employment of impact factors exclusive of other considerations is not a recommended method of evaluating academic performance. Administrators, however, are often not in the same specialty as the applicants, and a simple metric that allows making comparisons among candidates is appreciated and eagerly sought. A standard method of evaluation is also preferable to decisions being made based on political ties or personal patronage (Tang \& Hu 2018). It is important to remember that ranking is not equivalent to 
evaluating performance (Gingras 2016), which has three dimensions: input, output, and impact (Sugimoto \& Larivière 2018). Getting a research project going and funded involves creativity and perseverance and is the first important step, followed by the second step of publication of results. Only then can the topic of impact be addressed. A fair evaluation, therefore, needs to consider all these steps - not just impact (Lane et al. 2014).

Interest in impact factors developed many years ago through efforts by librarians to make decisions on which journals should be purchased for their library clientele. The first quantitative effort in this regard was by Gross and Gross (1927) who argued that the most frequently cited journals are the most relevant to the field. They recommended counting references during a year (or years) that are cited in a journal publication and ranking the journals that are cited based on the number of citations for each. This simple approach favored large journals over smaller ones, or frequently issued journals over less frequently issued ones, and of older journals over newer ones. Estelle Brodman (1944) tested the Gross and Gross method against opinions of professional medical physiologists at Columbia University, but she found little positive correlation, which cast doubt on the method.

Things changed completely with innovations from Eugene Garfield, who sought a better method of evaluating journals. In 1955 he published his concept of a scientific citation index, and this led to his founding in 1956 of the company Documentation, later called the Institute for Scientific Information (Wouters 2017). Garfield developed the Science Citation Index as a means of evaluating which journals should be listed in Current Contents, a weekly booklet that he published that presented the contents of the major journals. The objective again was to evaluate which journals were the major ones and hence to be included. Garfield sold his database in 1992 to Thomson Reuters, which morphed into the Clarivate Analytics Web of Science (Wouters 2017) that continues to this day.

Garfield's metric of impact factor was simple. One takes the total number of articles published in a journal for a twoyear period, and then counts how many of these articles have been cited in the following $\left(3^{\text {rd }}\right)$ year from all the articles contained in the Thomson Reuters database (more than 16,000 journals). The number of articles divided into the total cited in the third year results in the impact factor. For example, if a journal contained 100 articles during a two-year period, and in the third year there were 300 citations from that journal, the impact factor would be 3.00 . The range of impact among scientific journals ranges widely, from the top tier in Nature and Science (41) down to under 0.200. Journals that are not published regularly or that are not in English receive no ranking at all. The criteria are transparent so that a journal can adjust to appear in the ranking if they wish (or are able to do so).

In a competitive world, it is no surprise that once impact factors became accepted, journals adjusted their strategies so that their numbers would increase. The acceptable approaches included: publishing more issues per year; accepting higher quality papers (usually meaning higher rejection rates); publishing more reviews or symposia (Ketcham \& Crawford, 2007); soliciting manuscripts from well-known authors; improving the appearance of the journals through better design, use of color, etc. Some less scrupulous journals have also attempted "coercive citation" whereby the editor pushes authors to cite their own journal, or even worse "citation stacking" where editors in two different journals agree to push citations of the other's journal in their own published articles. The most disreputable strategy might be "self-citation" whereby a journal maneuvers to cite massive amounts of its own journal articles in editorials.

However useful, impact factors are not free from problems, as many persons have pointed out (e.g., Gingras 2016). Because the criteria for inclusion for ranking requires regular publication, irregular monograph series are automatically excluded. Furthermore, the journals must be in English, which also removes local or regional journals in other languages, such as Spanish, from consideration. The Thomson Reuters Scientific data base also does not include all scientific journals in the world. Even more problematical is that the index gives a measure of citations from a journal that could, in fact, all derive from only one article of an extremely broad or ground-breaking nature. A mediocre paper in this same journal, therefore, can be carried along to higher impact number because of these few highly visible publications.

All of the above considerations are not particularly controversial if they are kept to the focus of selection of journals for purchase in libraries. The difficulties arise when the impact factors are used to evaluate individual scientists. Before impact factors were invented, professionals in different fields evaluated published work by a number of commonsense criteria. Journals were always rated informally, with some having high regard and others less so. The good journals are edited to a high quality level, and they tend to have good turn-around time from submission to publication. They also tend to have regular and frequent issues and lower levels of acceptance of submitted articles, which affords them higher prestige. Many journals are sponsored by professional academic societies, but the level of quality can be quite variable. As for the articles themselves, papers that are very broad in scope, provide novel insights, or offer deep considerations of an issue are usually valued more highly than 
smaller observational papers. In other words, interpretative or synthetic papers often are regarded as more stimulating to development of a scientific community than descriptive ones.

In general, there can be little dispute that science, and indeed many aspects of human endeavor, have become more quantified in recent decades. Because of the increasing complexity of human society, enlarging population, and innovations in digital technology, this is likely to continue into the future (Philipps 2016). To ignore these developments would be unproductive, which leaves the challenge of determining the proper role of quantification in evaluation of scientific achievement. Encouraging staff researchers to publish in international and more visible journals is laudable, and this can work to the benefit of the individual as well as the institution. However, this quest for higher impact can sometimes interfere with appreciation and encouragement of research that an individual is best suited to produce. Furthermore, institutions may set impact goals that are tied directly to salary, cash bonuses (Abritis et al. 2017), or other aspects of career development, which can led to negativism and lowering of morale.

Problems with impact factors have resulted in attempts to provide more meaningful indices of performance evaluation. A new field has developed, bibliometrics (Pritchard 1969), which focuses on quantitative dimensions of production, dissemination, and use of documented information (TagueSutcliffe 1992). Because so much money is given to support research investigations in the world on a yearly basis, it is little wonder that developments for evaluation and accountability are occurring. One alternative to the impact factor is the $h$-index (Hirsch 2005), which quantifies the highest number of articles by an author that has the same number of citations (e.g., 15 articles being cited 15 times, or $h=15$ ). But as Gingras (2016) has shown, this also has problems in that it combines in an arbitrary way the number of published articles with the number of their citations, and it is also correlated with the total number of publications and hence not independent from impact factors. In addition to these innovations, two new databases are now being used to search for impact, Scopus and Google Scholar (Sugimoto \& Larivière, 2018), each containing a different set of indexed journals, but with considerable overlap (and also with the Web of Science). It has also been suggested that "altmetrics" might be more appropriate, or at least also important to examine to determine impact. These would involve citations or discussions on Twitter, blogs, or bulletin boards (Priem 2014), but at present there is no simple way to access these data for administrative purposes. A more difficult area of impact to evaluate are the readers that use the information from a publication, but do not themselves publish anything from it (i.e., non-publishing researchers, or even teachers; Haustein 2014).

Previously, workers in institutions in Latin America with small library holdings were unable to compete easily on an international level, simply because they did not have ready access to the existing literature. Without the ability to know what had been done on a particular problem, it became impossible to make original contributions. With this realization, many qualified researchers, even those obtaining their degrees in developed countries such as the U.S.A. or Europe, returned to home institutions in developing countries and realized they were unable to complete on the international scene because of lack of literature access. This forced them to dedicate to regional or local research questions that led to publications in lower impact journals. Only exceptional workers who maintained strong contacts to laboratories in developed countries and obtained funds to travel to major libraries on a periodic basis were able to compete at an international level. All of the discussion about impact factors might be regarded as academic if access to the world's literature were not possible, but the Internet is now accessible to most laboratories throughout Latin America, and much of the current, as well as older, botanical literature is now accessible.

Impact factors are not going to go away because they are a useful administrative tool. Even with recent support for a broader perspective in evaluation of research performance (e.g., DORA; Bladek 2014), and despite comments about the negative aspects of impact factors for researchers in developing countries (e.g., Rochmyaningsih 2017), impact factors are a way of life, and we must adapt to them (Tregoning 2018). It makes sense for researchers, therefore, to adjust to impact factors for professional (and institutional) benefit. The key is to develop a career strategy that insures a sufficient level of publications per year in qualifying journals (as determined by the home institutions) while at the same time allowing more descriptive research work to proceed. Realistic planning is the key. For example, an investigator with primary interest in botanical monography can work along on a revision of a group while being alert to interesting general biogeographic or evolutionary aspects that might be published in higher impact outlets. These might profitably be done in collaboration with workers from international laboratories, with the end result being higher impact papers and eventually a valuable monograph that may well have no impact statistic. It would be a jaded administrator who would not celebrate a person who produces articles in international journals as well as high quality work in local or regional outlets. 


\section{ENGLISH PROFICIENCY}

Because of widespread availability of the Internet, the challenge has shifted now from obtaining literature to being able to read it and understand it. This requires proficiency in English, which can only by its nature lead to more international perspectives and activities. With deliberate programs for English enhancement beginning in primary and secondary schools, by the time students arrive at the university, dealing with classes taught in English should be no special burden. This does not mean necessarily that all university courses must be given in English, but certainly for students who plan careers in the sciences, it should be strongly encouraged, if not required.

There is nothing magical about English. It is simply the modern scientific language that is used throughout the world to facilitate communication. In the $17^{\text {th }}$ century, Latin was the dominant language, followed by French into the early $18^{\text {th }}$ century. As the century rolled forward and the German botanical institutions became prominent, German became the next major scientific language. This was reduced somewhat after WWI, and it was effectively replaced by English after WWII, which continues to this day. Historically, therefore, there has always been a preferred international scientific language and for active scientists to have international impact, they must communicate in that medium.

A good case in point has been the recent Latin American Botanical Congress at Quito, Ecuador, in October of 2018. Most of the talks were presented in Spanish (some in Portuguese), and a very few in English, mainly by invited international speakers who simply were not skilled in Spanish. It is important to consider what the objective of this large meeting really is. If it is to provide a forum by which persons in Latin America can talk to each other, then having talks in Spanish or Portuguese makes complete sense. However, if the objective is for investigators in Latin America to talk to workers in the rest of the world regarding themes of interest in the flora of Latin America, then the strategy is not well designed to be inviting for international participants. Having the meeting in English is the only way to make this work successfully. Another solution to this problem would be to have simultaneous translation for all talks, but the costs for such a service would be prohibitively high. Obviously, local conferences held within countries of Latin America would continue to be conducted in Spanish or Portuguese.

A positive example of the gains from English acquisition is what has happened in China. Nearly two decades ago, Beijing University made a decision to teach General Biology to their undergraduate students in English (Yan-Ping Guo, pers. comm.). This, plus similar approaches in other universities and scholarship programs to allow promising students to pursue graduate studies in English-speaking countries, has resulted in the younger generation being very fluent in English. Of course, the economy of China has developed at the same time, which has resulted in a huge generation of new wealth. This has facilitated the funding of linguistic initiatives as well as scientific advances. With the development of improved scientific infrastructure, greater exposure to international laboratories, and English proficiency, many high quality papers are now appearing. While Latin America is different from China in many respects, the Chinese example does show how it is possible to have more successful international scientific impact with considerable effort and focus. China became the third-largest producer of research articles in 2014 (Morrison 2014) and has now just surpassed the U.S.A. in total scientific output (Tollefson 2019).

A very useful analogy at the meeting in Quito was mentioned to me by Karol Marhold, Secretary-General of the International Association of Plant Taxonomists. He lives and works in Bratislava of the Slovak Republic and is very familiar with Slavic countries, especially Russia. He pointed out that we in the Western scientific world do not know what is presently going on with Russian botany, and the main reason is that the Russian-speaking botanists meet together and they often speak only in Russian to each other, hence largely excluding the rest of the world. This interferes with international collaborations and significantly isolates Russian science. Latin America does not need to self-restrict itself in this same way.

\section{ACKNOWLEDGMENTS}

Thanks go to Hugo Valdebenito, Vice-President of the Latin American Botanical Congress (Quito, Ecuador, October 2018), for the kind invitation to attend the meeting and present the inaugural lecture (in Spanish), which forms a significant portion of this article. The discussion on impact factors came in part from my talk (presented in English) in a symposium organized by Alina Freire-Fierro and Hugo Valdebenito on impact factors in Latin America at the XIX International Botanical Congress (Shenzhen, China, July 2017).

\section{REFERENCES}

Abritis, A., Mccook, A., Retraction Watch. 2017. Cash incentives for papers go global. Science 357: 541.

Basset, Y., Novotny, V., Miller, S.E., Pyle, R. 2000. Quantifying biodiversity: experience with parataxonomists and digital 
photography in New Guinea and Guyana. Bioscience 50: 899-908.

Basset, Y., Novotny, V., Miller, S.E., Weiblen, G.D., Missa, O., Stewart, A.J.A. 2004. Conservation and biological monitoring of tropical forests: the role of parataxonomists. Journal of Applied Ecology 41: 163-174.

Bladek, M. 2014. DORA: San Francisco Declaration on Research Assessment (May 2013). College and Research Libraries News, April: 191-196.

Brodman, E. 1944. Choosing physiology journals. Bulletin of the Medical Library Association 32: 479-483.

Garfield, E. 1955. Citation indexes for science. A new dimension in documentation through association of ideas. Science 122: 108-111.

Gingras, Y. 2016. Bibliometrics and Research Evaluation: Uses and Abuses. MIT Press, Cambridge. 119 pp.

Gross, P.L.K., Gross, E.M. 1927. College libraries and chemical education. Science 55: 385-389.

Haustein, S. 2014. Readership metrics. In: Cronin, B., Sugimoto, C.R. (Eds.), Beyond Bibliometrics: Harnessing Multidimensional Indicators of Scholarly Impact, pp. 327344. MIT Press, Cambridge.

Hirsch, J.E. 2005. An index to quantify an individual's scientific research output. Proceedings of the National Academy of Sciences of the USA 102: 16569-16572.

Janzen, D.H. 1991. How to save tropical biodiversity: The National Biodiversity Institute of Costa Rica. American Entomologist 37: 159-171.

Janzen, D.H., Hallwachs, W. 2011. Joining inventory by parataxonomists with DNA barcoding of a large complex tropical conserved wildland in northwestern Costa Rica. PLoS ONE 6(8): e18123. DOI: 10.1371/journal. pone. 0018123

Joppa, L.N., Roberts, D.L., Myers, N., Pimm, S.L. 2011. Biodiversity hotspots house most undiscovered plant species. Proceedings of the National Academy of Sciences of the USA. 108: 13171-13176.

Ketcham, C.M., Crawford, J.M. 2007. The impact of review articles. Laboratory Investigation 87: 1174-1185.

Kier, G., Mutke, J., Dinerstein, E., Ricketts, T.H., Küper, W., Kreft, H., Barthlott, W. 2005. Global patterns of plant diversity and floristic knowledge. Journal of Biogeography 32: 1107-1116.

Krell, F.-T. 2004. Parataxonomy vs. taxonomy in biodiversity studies - pitfalls and applicability of 'morphospecies' sorting. Biodiversity and Conservation 13: 795-812.

Lane, J., Largent, M., Rosen, R. 2014. Science metrics and science policy. In: Cronin, B., Sugimoto, C.R. (Eds.), Beyond Bibliometrics: Harnessing Multidimensional Indicators of Scholarly Impact, pp. 397-411. MIT Press, Cambridge.
López, P., Tremetsberger, K., Kohl, G., Stuessy, T. 2012. Progenitorderivative speciation in Pozoa (Apiaceae, Azorelloideae) of the southern Andes. Annals of Botany 109: 351-363.

Marhold, K., Stuessy, T. (Eds.) 2013. The future of botanical monography: Report from an international workshop, 1216 March 2012, Smolenice, Slovak Republic. Taxon 62: 4-20.

Mathias, M.E., Constance, L. 1962. A revision of Asteriscium and some related hydrocotyloid Umbelliferae. University of California Publications in Botany 33: 99-184.

Mayo, S.J., Allkin, R., Baker, W., Blagoderov, V., Brake, I., Clark, B., Govaerts, R., Godfray, C., Haigh, A., Hand, R., Harman, K., Jackson, M., Kilian, N., Kirkup, D.W., Kitching, I., Knapp, S., Lewis, G.P., Malcolm, P., Von Raab-Straube, E., Roberts, D.M., Scoble, M., Simpson, D.A., Smith, C., Smith, V., Villalba, S., Walley, L., Wilkin, P. 2008. Alpha e-taxonomy: responses from the systematics community to the biodiversity crisis. Kew Bulletin 63: 1-16.

Monasterio, M., Sarmiento, L. 1991. Adaptive radiation of Espeletia in the cold Andean tropics. Trends in Ecology and Evolution 6: 387-391.

Morrison, J. 2014. China becomes world's third-largest producer of research articles. Nature. DOI: 10.1038/ nature.2014.14684.

Penneckamp Furniel, D. 2018. Flora Vascular Silvestre del Archipiélago Juan Fernández. Ministerio de Ciencias, Artes, y Patrimonio and Museo Nacional de Historia Natural, Santiago. 723 pp. (Digital version only).

Philipps, C.J. 2016. Quantifying culture. Science 354: 45.

Pimm, S.L., Joppa, L.N. 2015. How many plant species are there, where are they, and at what rate are they going extinct? Annals of the Missouri Botanical Garden 100: 170-176.

Priem, J. 2014. Altmetrics. In: Cronin, B., Sugimoto, C.R. (Eds.), Beyond Bibliometrics: Harnessing Multidimensional Indicators of Scholarly Impact, pp. 263-287. MIT Press, Cambridge.

Prichard, A. 1969. Statistical bibliography or bibliometrics? Journal of Documentation 24: 348-349.

Reid, W.V., Laird, S.A., Meyer, C.A., Gámez, R., Sittenfeld, A., Janzen, D.H., Gollin, M.A., Juma, C. 1993. Biodiversity Prospecting: Using Genetic Resources for Sustainable Development, Annex 1 - The role of the parataxonomists, inventory managers, and taxonomists in Costa Rica's National Biodiversity Inventory, pp. 223-254. A World Resources Institute Book, Washington, D.C.

Rochmyaningsih, D. 2017. The developing world needs more than numbers. Nature 542: 7.

Schmiedel, U., Araya, Y., Bortolotto, M.I., Boeckenhoff, L., Hallwachs, W., Janzen, D., Kolipaka, S.S., Novotny, V., Palm, M., Parfondry, M., Smanis, A., Toko, P. 2016. 
Contributions of paraecologists and parataxonomists to research, conservation, and social development. Conservation Biology 30: 506-519.

Sklenáŕ, P. 1999. Nodding capitula in superpáramo Asteraceae: An adaptation to unpredictable environment. Biotropica 31: 394-402.

Stuessy, T.F. 1975. The importance of revisionary studies in plant systematics. Sida 6: 104-113.

Stuessy, T.F. 1993. The role of creative monography in the biodiversity crisis. Taxon 42: 313-321.

Stuessy, T.F., Lack, H.W. (Eds.) 2011. Monographic Plant Systematics: Fundamental Assessment of Plant Biodiversity. A.R.G. Gantner Verlag, Ruggell. 222 pp.

Sugimoto, C.R., Larivière, V. 2018. Measuring research: what everyone needs to know. Oxford University Press, New York. 149 pp.

Sundberg, S., Stuessy, T.F. 1990. Isolating mechanisms and implications for modes of speciation in Heliantheae (Compositae). Plant Systematics and Evolution, Suppl. 4: 77-97.

Tague-Sutcliffe, J. 1992. An introduction to informetrics. Information Processing \& Management 28: 1-3.

Tang, L., Hu, G. 2018. Evaluation woes: metrics beat bias. Nature 559: 331.
Tollefson, J. 2019. China declared world's largest producer of scientific articles. Nature 553: 390.

Tregoning, J. 2018. How will you judge me if not by impact factor? Nature 558: 345.

Ulloa Ulloa, C., Acevedo-Rodríguez, P., Beck, S., Belgrano, M.J., Bernal, R., Berry, P.E., Brako, L., Celis, M., Davidse, G., Forzza, R.C., Gradstein, S.R., Hokche, O., León, B., León-Yánez, S., Magill, R.E., Neill, D.A., Nee, M., Raven, P.H., Stimmel, H., Strong, M.T., Villaseñor, J.L., Zarucchi, J.L., Zuloaga, F.O., Jørgensen, P.M. 2017. An integrated assessment of the vascular plant species of the Americas. Science 358: 1614-1617.

Villaseñor, J.L. 2016. A checklist of the native vascular plants of México. Revista Mexicana de Biodiversidad 87: 559-902.

Wen, J., Ickert-Bond, S.M., Appelhans, M.S., Dorr, L.J., Funk, V.A. 2015. Collections-based systematics: opportunities and outlook for 2050. Journal of Systematics and Evolution 53: 477-488.

Wouters, P. 2017. Eugene Garfield (1925-2017). Inventor of the Science Citation Index. Nature 543: 492.

Zuloaga, F.O., Morrone, O., Belgrano, M.J. (Eds.). 2008. Catálogo de las Plantas Vasculares del Cono Sur (Argentina, Sur de Brasil, Chile, Paraguay y Uruguay), vols. 1-3. Missouri Botanical Garden, St. Louis. 3348 pp.

Received: 02.10.2019

Accepted: 14.01.2020 